\title{
Izobraževanje za vse
}

"Potrebujemo informirane ženske in moške, ki uspešno delujejo na vseh področjih življenja, če hočemo, da bo človeštvo preživelo in se soočalo z izzivi prihodnosti.«

(Hamburška deklaracija, UNESCO, 1997)

$V$ svetu potekajo pomembna gibanja in dogodki v zvezi z izobraževanjem, o katerih $v$ Sloveniji premalo slišimo. Radi bi vam predstavili dve svetovni konferenci oziroma njune sklepe. Gre namreč za resnične mejnike na področju učenja in izobraževanja posameznikov.

Pod okriljem Združenih narodov in s podporo različnih vladnih in nevladnih organizacij poteka gibanje, imenovano „Izobraževanje za vse» (EFA - Education for All). To gibanje se je začelo s svetovno konferenco Izobraževanje za vse, ki je bila leta 1990 v Jomtienu na Tajskem. Od takrat v strokovnih krogih govorijo o sjomtienskem desetletju«, saj je postala konferenca mejnik v prizadevanjih za pridobivanje znanja.

Vlade so dolžne zagotoviti temeljne življenjske možnosti vsem svojim državljanom. Na jomtienski konferenci je svetovna javnost priznala, da je na današnji stopnji razvoja znanje tako zelo pomembno za življenje, kot sta za ljudi pomembna zrak ali kruh. Zato družba nikomur ne sme odreči možnosti, da se izobražuje. Brez znanja je posameznik zapisan socialni in biološki smrii.

Ekonomsko vitalnost določene družbe in njene možnosti za razvoj ter poloz̆aj v svetovnih razmerjih merijo raziskovalci pri Združenih narodih po podatkih a stanju prebivalstva.

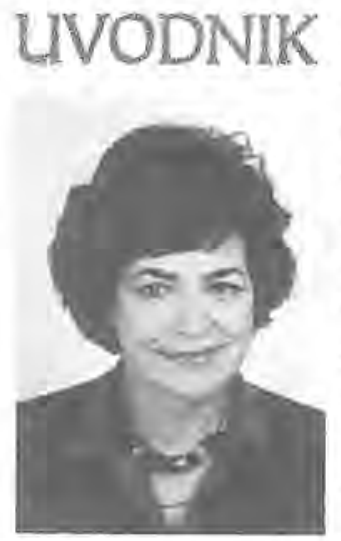

Dr: Ana Krajnc
Upoštevajo na primer povprečno število let solanja na prebivalca, nepismenost ljudi, stopnjo funkcionalne pismenosti, pričakovano življenjsko dobo, umrljivost dojenčkov itd. Njihova pozornost se ne osredotoča ver̃ na nahajališca surovin, strojno opremo in podobno, temveč se vse bolj posveča posameznikom. Človek kot vrednota je vse pomembnejši v primerjavi z drugimi vrednotami tudi $v$ državah, kjer tega na prvi pogled ne bi pričakovali.

Gonilna sila ekonomije v informacijski družbi so izvirne, nove zamisli, izumi, komunikacija, pa tudi ustvarjalnost, kritičnost in empatija. Ekonomski napredek zahteva posameznike z razvito osebnostjo, vzgojene, izobražene in dobro poučene.

»Kdo si lahko to sploh privošči? Kdo ima dostop do izobraževanja in znanja? Komu in kako so zagotovljene možnosti za razvijanje osebnosti? Je izobraževanje dostopno vsem otrokom, mladini in odraslim? so se spraševali na svetovni konferenci v Jomntienu. Ponovno so potrdili eno temeljnih človekovih pravic: pravico do izobraževanja in osebnega razvoja brez omejitev ter diskriminacije. Predstavniki držav članic ZN naj bi spoznali, kaj je v vzgoji ter izobraževanju potrebno in možno, ter se zamislili nad položajem v lastni državi. Za nadaljnjih deset let so pripravili smernice za razvoj »izobraževanja za vse๘.

Svetovno družbeno gibanje Izobraževanje za vse naj bi podprle in uresničevale vladne in tudi nevladne organizacije. Izobraževanje naj ne bi bilo samo šolsko, formalno, marveč so poudarili pomen neformalnega izobraževa- 
nja in kulturne ter družbene zavzetosti posameznikov za izobraževanje in osebnostno rast. Med seboj se naj bi povezali različni dejavniki okolja. Tako bi se izobraževalne možnosti prebivalstva občutno povečale.

Po desetih letih so ocenjevali uspehe in neuspehe izobraževanja za vse (EFA).

Svetovni forum za izobraževanje se je zbral aprila 2000 v Dakarju v Senegalu, Države članice Združenih narodov so na konferenco poslale svoje ministre za izobraževanje, navzoči so bili tudi predstavniki nevladnih organizacij, delegati Svetovne banke in strokovnjaki, specialisti, znanstveniki z raznih inštitutov z vsega sveta. Zbralo se je približno 1.500 udeležencev, da bi ocenili, kako uspešno in po kakšnih poteh omogočajo različno združevanje za izobraževanje vsem posameznikom.

Na Svetovnem forumu za izobraževanje so sprejeli te sklepe:

- sredstva za pismenost in izobraževanje odraslih naj bi se povečala v skladu s priporočili svetovnega vrha za socialni razvoj in Unescove konference o izobraževanju odraslih v Hamburgu;

- podpirati je treba izobraževanje otrok ter mladine in izobraževanje odraslih, $k i$ že igrajo dejavno ekonomsko, družbeno in politično vlogo v skupnostih, kjer živijo;

- pismenost in izobraževanje odraslih sta sredstvo, s katerim lahko posamezniki premagajo revščino in izločenost, dosežejo pravičnost in mir, ekonomsko ter socialno blaginjo, okrepijo demokracijo in si izboljšajo zdravje;

- razvoj pismenosti, izobraževanja odraslih in vseživljenjskega izobraževanja zelo ovirajo različni dejavniki, kot so etnični konflikti, prisilne preselitve, tuja nadvlada, nepriznavanje pravic posameznih skupnosti in nenehno povečevanje vojaških zmogljivosti;

- razen pri nekaterih izjemah je opaziti, da države grobo zanemarjajo ali pa sploh ne vključujejo pismenosti in politike izobraževanja odraslih, čeprav so vlade držav članic $Z N$ odgovorne za izvajanje sprejetih dokumentov;

- parmerstvo med vladami, prostovoljnimi organizacijami in drugimi skupinami civilne družbe se ni razvijalo v skladu s pričakovanji, mednarodna gibanja za pismenost in izobraževanje odraslih so še zmeraj prešibka, da bi spremljala odločanje glede izobraževanja na globalni nacionalni in regionalni ravni.

Na Svetovnem forumu za izobraževanje so ugotavljali: "... ni mogoče čakati na naslednjo generacijo, ki bo bolje šolana, potreba po informiranem in ustvarjalnem sodelovanju ljudi je takojšnja. Negotovost in tveganje, $s$ katerima se soočajo državljani, brez odlašanja zahtevajo podporo ustvarjalnemu delovanju ljudi in povečanju njihovih zmožnosti. Po svetu imamo dovolj znanja in izkušenj o tem. kako izobraževanje odraslih podpira ljudi in do kakšnih sprememb lahko pripelje. Čas je, da izobraževanje postane izobraževanje za vse.« (Dakar, 2000, Education for All)

Ugledna in vplivna organizacija Mednarodni svet za izobraževanje odraslih je v podporo postavljenim ciljem navedla, da je treba:

- ustanoviti učinkovite svetovne strukture za spodbujanje pismenosti in izobraževanja odraslih;

- napraviti študijo o stanju v izobraževanju odraslih v svetu;

- razširiti po svetu Teden odraslih učencev Združenih narodov;

- organizirati $k$ dejavnostim naravnano svetovno konferenco različnih organizacij civilne družbe, ki se ukvarjajo s pismenostjo, izobraževanjem odraslih in vseživljenjskim izobraževanjem, v avgustu 2001 na Jamajki (Adult Education and Development, 55, 2000, str. 13). 
Večino bremena izobraževanja za vse nosijo države same. Njihova prva naloga je, da najprej napravijo svoj načrt, kako bodo zagotovile takšno izobraževanje. Nedvomno bo pri tem treba upoštevati tudi razpoložljive gmotne vire in določiti prednostne cilje.

Poudariti želimo predvsem nekatere sklepe dakarskega Svetovnega foruma za izobraževanje:

- izobraževanje za vse naj bi bilo namenjeno slehernemu državljanu in vsem družbam;

- vlade so odgovorne za to, da izobraževanje za use doseže postavljene cilje in naloge;

- otroci, mladina in odrasli imajo osnovno pravico do izobraževanja v skladu z, svojimi temeljnimi učnimi potrebami - pravico do izobraževanja, ki jih usposablja za učenje, delo, življenje in obstoj;

- š vnaprej naj bi pozornost posvečali temeljnemu izobraževanju, ki so ga podprli različni forumi v devetdesetih letih;

- brez izobraževanja za vse se bosta povečevali revščina in neenakost med državami ter v posameznih družbah;

- izobraževanje je ključ do razvoja, miru in stabilnosti držav, ki so v 21. stoletju pod močnim vplivom globalizacije; treba je doseči, da se zadovoljijo temeljne potrebe useh ljudi po učenju;

- sleherna država bo najpozneje do leta 2002 morala predložiti svoj nac̆rt o tem, kako bo uvedla izobraževanje za vse;

- za učinkovito uresničevanje nacionalnega načrta potrebujemo politično voljo in vplivnejšse nacionalno vodstvo;

- mednarodna skupnost bo z iskanjem dodatnih sredstev in razvijanjem strategij podpirala nacionalne načrte za izobraževanje za vse;

- nekatere države so že vzorno poskrbele za izobraževanje za vse, nekatere zaostajajo in jih bo mednarodna skupnost morala po- sebej podpreti (države v tranziciji, države, kjer vladajo konfliktne razmere, in države po kriznem obdobju); prednost pri pridobivanju pomoči imajo države Podsaharske Afrike, Južne Azije in najmanj razvite dr. žave.

Potrebo po izobraževanju za vse srečujemo povsod po svetu, v vsaki državi. Razvoja družbe danes več ne rešuje le peščica intelektualcev kot nekoč. Odgovornost se vse bolj prenasa na posameznike in ti morajo biti temu kos. Napačne odločitve in napačno ukrepanje škodujejo posamezniku in družbi. Vitalnost določene družbe pa je odvisna od stopnje izobraženosti prebivalstva. Zaman sanjamo o demokraciji, če posamezniki zanjo nimajo znanja. Demokracija brez znanja se zlahka spremeni $v$ nasilje.

Deklaracije Unesca in Svetovnega foruma za izobraževanje pa bodo le mrtev popisan papir, če jih ljudje ne bodo znali udejanjiti. Zamisel izobraževanja za vse zveni včasih utopično, povsem neuresničljivo. Pridružimo se Paulu Lengrandu, ki na to odgovarja: "To je utopija, vendar utopija, ki jo že živimo. Tako je potreba, da se izobražuje sleherni posameznik, postala resničnost. Koncept vseživljenjskega izobraževanja in izobraževanja za vse stopata z roko v roki.

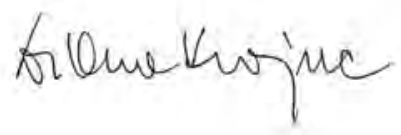

